\title{
NONINVASIVE IDENTIFICATION OF INDIVIDUAL AMERICAN BADGERS BY FEATURES OF THEIR DORSAL HEAD STRIPES
}

\author{
Robert L. Harrison ${ }^{1}$
}

\begin{abstract}
Aвstract-_Identification of individual animals is a valuable and often essential procedure for studies of animal behavior and population size. I present evidence that individual American badgers (Taxidea taxus) may be identified by natural features of their dorsal head stripes.

RESUMEN.-La identificación individual de los animales es un procedimiento importante y, a menudo, esencial para estudiar el comportamiento animal y el tamaño de las poblaciones. Presento evidencia de que los individuos de tejón americano (Taxidea taxus) pueden ser identificados por características naturales como sus rayas dorsales en la cabeza.
\end{abstract}

Identification of individual animals is a valuable and often essential procedure for studies of animal behavior and estimates of population size (Lancia et al. 2005, Silvy et al. 2005). A great variety of methods have been used to identify (i.e., mark) individuals, including radio-collaring, dyeing, painting, toe-clipping, ear-tagging, leg-banding, insertion of passive integrated transponder (PIT) tags, genetic analysis of hair or scat, and observation of natural markings such as patterns in fur and skin (DeYoung and Honeycutt 2005, Silvy et al. 2005). In particular, identification of individuals by natural markings combined with subsequent observation with automatic digital cameras enables studies of free-ranging animals without the risk and expense of capture or other direct interaction (Animal Care and Use Committee 1998). This method is particularly well suited to studies of low-density, solitary, nocturnal, or difficult-to-capture species such as many carnivores (Negrões et al. 2010, Magoun et al. 2011).

Previous studies involving individually identified American badgers (Taxidea taxus) have used radio-collaring (Collins et al. 2012), radio-implanting (Goodrich and Buskirk 1998), genetics (Ministry of Environment 2007), and tattooing and ear-tagging (Messick and Hornocker 1981). In studies of Eurasian badgers (Meles meles), researchers have used hairclipping (Stewart and Macdonald 1997), genetics (Wilson et al. 2003, Frantz et al. 2004), radiocollaring and attachment of lights (Tuyttens et al. 1999), and variations of pelage patterns in tails (Dixon 2003). In addition, Clark (2010) used variations of facial pelage to identify individual members of a social group. In this report, I present evidence that individual American badgers (hereafter, badgers) may be identified by natural features of their dorsal head stripes.

Fieldwork was conducted in the northern Chihuahuan Desert on the 142,000-ha Armendaris Ranch, a private ranch in Sierra and Socorro Counties in south central New Mexico. Habitat within the study area was dominated by black grama grass (Bouteloua eriopoda) and shrubs creosotebush (Larrea tridentata), honey mesquite (Prosopis glandulosa), longleaf jointfir (Ephedra trifurca), sand sagebrush (Artemisia filifolia), and little-leaf sumac (Rhus microphyllum). Topography was flat or low rolling hills, and elevations were 1300-1500 m. Annual precipitation falls mostly in summer and fall, and averaged $23.6 \mathrm{~cm}$ from 1951 to 2010 (Western Regional Climate Center 2014). Average monthly minimum and maximum temperatures were $8.0^{\circ} \mathrm{C}$ and $23.7^{\circ} \mathrm{C}$, respectively, from 1951 to 2010 .

From May 2012 through March 2014, I deployed automatic digital cameras (Reconyx [Holmen, WI] HC600 or PC900) at wildlife water sources and survey stations for studies of badger survey methods and behavior (Harrison 2015, 2016). Early in those studies I observed that patterns of black and white pelage within badgers' white dorsal head stripes

${ }^{1}$ Department of Biology, University of New Mexico, Albuquerque, NM 87131. E-mail: rharison@unm.edu 


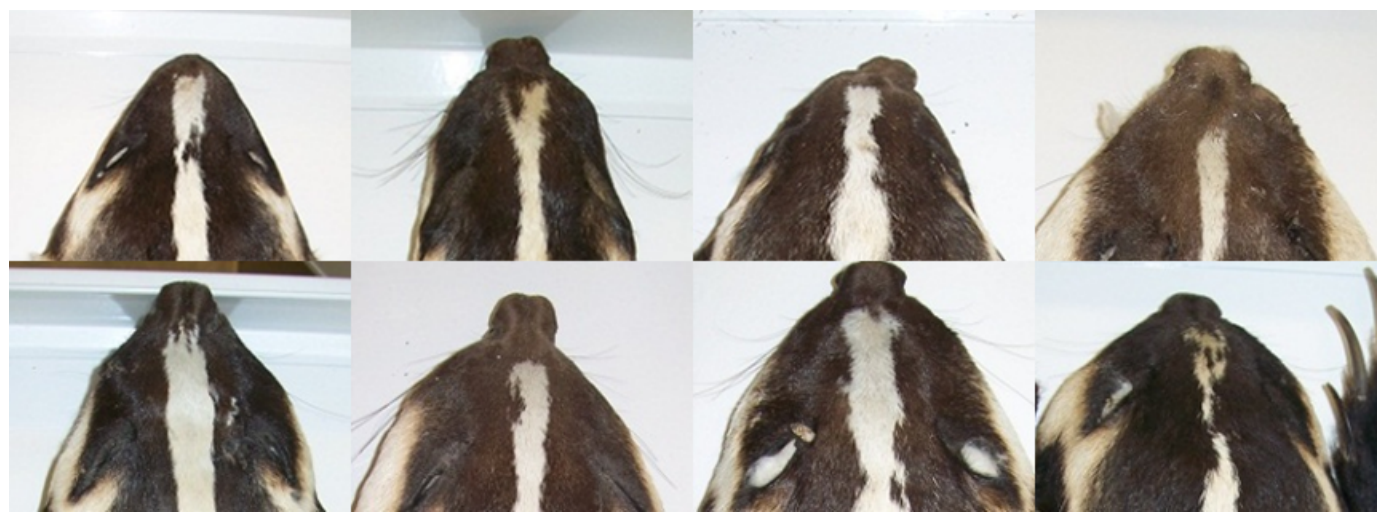

Fig. 1. Examples of heads of specimens of American badgers in the Museum of Southwestern Biology, University of New Mexico, showing variability between individuals of the patterns of black and white pelage within dorsal head stripes.

were variable and that badgers with the same specific pattern often were photographed more than once. Subsequently I twice photographed the heads of 21 badger specimens in the Museum of Southwestern Biology, University of New Mexico, Albuquerque, New Mexico (Fig. 1). Variability between the patterns of black and white $\mathrm{p}$ elage within white dorsal head stripes of individual badgers was readily apparent, but I tested the likelihood of confusing 2 badgers by separating the 2 sets of photographs into sets $\mathrm{A}$ and $\mathrm{B}$, randomizing the order of photographs in each set, and then attempting to match each badger from set $\mathrm{A}$ with a badger from set B. After finding a match, I set aside the set A photograph, and rerandomized set $\mathrm{B}$ without removing the matched badger's set B photograph. I successfully matched all 21 badgers with no mismatches. In contrast, I found no useful variation between the dark "badges" on the sides of badgers' heads. I also found that white dorsal stripes extending along badgers' backs were not useful features for individual identification due to potential movement of the long hair on the back.

During a badger population survey from June to August 2012, 183 camera-weeks of observation were obtained during which badgers were observed 343 times, of which 145 observations yielded a badger identification. A total of 30 individual (i.e., unique) badgers were observed and identified. The number of times an individual badger was identified ranged from 1 to 20 and averaged 4.8. Individual badgers were identified during both nighttime (infrared illumination) and daytime (sunlight) with no confounding effect of lighting. I was able to identify the same individuals throughout the entire survey period, confirming that pelage patterns of dorsal head stripes did not vary sufficiently during the short survey period to confuse identifications. Furthermore, individuals observed during the population survey were also identified subsequently during the remaining 19 months of the studies. During annual molt the shade of dark portions of badger pelage may change, but the overall pattern of white and darker hair does not change (Long 1975, Dixon 2003).

In combination with automatic cameras, noninvasive population surveys and studies of density or movements which require individual identification of badgers are now possible (Harrison 2015) without the complications of genetic analysis. However, badger skull lengths are <141 mm (Long 1973) and discriminatory features of patterns in head stripes are small. Thus, to identify a badger with this method, a close-up photograph or other close observation is necessary. In this study, badgers were photographed at water sources or stations using bait or scent lures which attracted badgers to specific small sites where they could be photographed at close range (Harrison 2015, 2016). Future studies should also consider employing additional observers to verify individual identifications.

Badgers in the study area and specimens examined at the Museum of Southwestern Biology (Fig. 1) were all of the subspecies Taxidea taxus berlandieri. Further research 
should be directed toward determining if other subspecies show similar variation of their dorsal head stripes. Also, although Dixon (2003) was able to discriminate between individuals of a social group of Eurasian badgers, it is generally unknown the extent to which pelage patterns are similar between related individuals.

I thank Mr. T. Turner and Mr. T. Waddell for permission to conduct this study on the Armendaris Ranch. I also thank the Museum of Southwestern Biology, University of New Mexico, for access to badger specimens.

\section{Literature Cited}

Animal Care and Use Committee. 1998. Guidelines for the capture, handling, and care of mammals as approved by the American Society of Mammalogists. Journal of Mammalogy 79:1416-1431.

Clark, M. 2010. Badgers. British Natural History Series. Whittet Books, Essex, United Kingdom.

Collins, D.P., III, L.A. Harveson, and D.C. Ruthven III. 2012. Spatial characteristics of American badgers (Taxidea taxus) in southern Texas. Southwestern Naturalist 57:473-478.

DeYoung, R.W., AND R.L. HoneycutT. 2005. The molecular toolbox: genetic techniques in wildlife ecology and management. Journal of Wildlife Management 69: $1362-1384$.

DIXON, D.R. 2003. A non-invasive technique for identifying individual badgers Meles meles. Mammal Review 33:92-94.

Frantz, A.C., M. Schaul, L.C. Pope, F. Fack, L. Schley, C.P. Muller, AND T.J. Roper. 2004. Estimating population size by genotyping remotely plucked hair: the Eurasian badger. Journal of Applied Ecology 41:985-995.

Goodrich, J.M., AND S.W. Buskirk. 1998. Spacing and ecology of North American badgers (Taxidea taxus) in a prairie-dog (Cynomys leucurus) complex. Journal of Mammalogy 79:171-179.

HARRison, R.L. 2015. A comparison of sign searches, livetrapping, and camera-trapping for detection of American badgers (Taxidea taxus) in the Chihuahuan Desert. Western North American Naturalist 75:387-395.

HARRISON, R.L. 2016. Badger behavior at anthropogenic water sources in the Chihuahuan Desert. Western North American Naturalist 76:1-5.
Lancia, R.A., W.L. Kendall, K.H. Polluck, and J.D. NichOLS. 2005. Pages 106-153 in C.E. Braun, editor, Techniques for wildlife investigations and management. The Wildlife Society, Bethesda, MD.

LONG, C.A. 1973. Taxidea taxus. Mammalian Species 26:1-4.

LONG, C.A. 1975. Molt in the American badger, Taxidea taxus. Journal of Mammalogy 56:921-924.

Magoun, A.J., C.D. Long, M.K. Schwartz, K.L. Pilgrim, R.E. LOWELL, AND P. VALKENBURG. 2011. Integrating motion-detection cameras and hair snags for wolverine identification. Journal of Wildlife Management 75: 731-739.

Messick, J.P., AND M.G. HonNOCKer. 1981. Ecology of the badger in southwestern Idaho. Wildlife Monographs $76: 1-53$.

Ministry of EnVironment, Ecosystems Branch For the Resources Information Standards CommitTeE. 2007. Inventory methods for medium-sized territorial carnivores: badger. Standards for Components of British Columbia's Biodiversity No. 25A. Resources Information Standards Committee, Victoria, BC.

Negrões, N., P. Sarmento, J. Cruz, C. Eira, E. Revilla, C. Fonseca, R. Sollmann, N.M. Tôrres, M.M. Furtado, AND A.T.A. JÀcomo, ET AL. 2010. Use of camera-trapping to estimate puma density and influencing factors in central Brazil. Journal of Wildlife Management 74:1195-1203.

Silvy, N.J., R.R. Lopez, and M.J. Peterson. 2005. Wildlife marking techniques. Pages 339-376 in C.E. Braun, editor, Techniques for wildlife investigations and management. The Wildlife Society, Bethesda, MD

Stewart, P.D., and D.W. Macdonald. 1997. Age, sex, and condition as predictors of moult and the efficacy of a novel fur-clip technique for individual marking of the European badger (Meles meles). Journal of Zoology, London 241:543-550.

Tuyttens, F.A.M., D.W. Macdonald, E. Swait, and C.L. Cheeseman. 1999. Estimating population size of Eurasian badgers (Meles meles) using mark-recapture and mark-resight data. Journal of Mammalogy 80: 950-960.

Western Regional Climate Center. 2014. Climate data [online]. http://www.wrcc.dri.edu

Wilson, G.J., A.C. Frantz, L.C. Pope, T.J. Roper, T.A. Burke, C.L. Cheeseman, and R.J. Delahay. 2003. Estimation of badger abundance using faecal DNA typing. Journal of Applied Ecology 40:658-666.

Received 25 June 2015 Accepted 8 February 2016 